SJ Quinney College of Law, University of Utah Utah Law Digital Commons

Utah Law Faculty Scholarship

Utah Law Scholarship

6-2019

\title{
Fostering Adaptive Marine Aquaculture through Procedural Innovation in Marine Spatial Planning
}

Robin Kundis Craig

S.J. Quinney College of Law, University of Utah, robin.craig@law.utah.edu

Follow this and additional works at: https://dc.law.utah.edu/scholarship

Part of the Environmental Law Commons, and the Natural Resources Law Commons

\section{Recommended Citation}

Craig, Robin Kundis, "Fostering Adaptive Marine Aquaculture through Procedural Innovation in Marine Spatial Planning" (2019). Utah Law Faculty Scholarship. 163.

https://dc.law.utah.edu/scholarship/163

This Article is brought to you for free and open access by the Utah Law Scholarship at Utah Law Digital Commons. It has been accepted for inclusion in Utah Law Faculty Scholarship by an authorized administrator of Utah Law Digital Commons. For more information, please contact

valeri.craigle@law.utah.edu. 


\title{
Fostering Adaptive Marine Aquaculture through Procedural Innovation in Marine Spatial Planning
}

\author{
Robin Kundis Craig ${ }^{a}$ \\ a CORRESPONDING AUTHOR. University of Utah S.J. Quinney College of Law, 383 South University St., Salt Lake City, \\ UT 84112 USA; robin.craig@law.utah.edu.
}

\begin{abstract}
Worldwide, as wild-caught commercial fisheries plateau and human demands for protein increase, marine aquaculture is expanding. Much marine aquaculture is inherently adaptable to changing climatic and chemical conditions. Nevertheless, siting of marine aquaculture operations is subject to competing environmental, economic, and social demands upon and priorities for ocean space, while some forms of marine aquaculture can impose other externalities on marine systems, such as pollution from wastes (nutrients) and antibiotics, consumption of wild fish as food, and introduction of non-native or genetically modified species. As a result, governmental policy decisions to promote both marine aquaculture that can adapt to a changing ocean and adaptive governance for that aquaculture can become contested, requiring attention to their social legitimacy.
\end{abstract}

This article explores how the law can promote the adaptability of marine aquaculture to climate change and ocean acidification-adaptive marine aquaculture-while still preserving key rule-of-law values, such as public participation and accountability. Perhaps most obviously, law can establish substantive requirements for marine aquaculture that minimize its impacts, promoting marine resilience overall. However, to foster truly adaptive marine aquaculture, including adaptive governance institutions, coastal nations should also procedurally reform their marine spatial planning efforts to legally connect the procedures for aquaculture permitting, marine spatial planning (MSP), and adaptive management. One goal of such connections, moreover, should be to mandate new forums for public participation and creative collaboration, promote experimentation with accountability that leads to increased knowledge, and foster the emergence of adaptive governance regarding the use of marine space.

\section{Introduction: The Need for Increased Flexibility in Managing Ocean Aquaculture and} the Risks to the Rule of Law

Worldwide, as wild-caught commercial fisheries plateau and human demands for protein increase, marine aquaculture, the controlled and generally confined raising of marine plants, 
shellfish, and fish in ocean waters [1-2], has been rapidly expanding [3-5]. In 2016, marine aquaculture represented over half (53\%) of global fish production for food [5: 2]. Moreover, while marine aquaculture growth has dropped from double digits per year in the 1980s and 1990s, it is still growing at a rate of slightly less than 6\% per year [5: 17]. Noting this trend, Gentry et al. [6] argue that much of the world's coastal ocean is biologically available for marine aquaculture.

The expansion of marine aquaculture raises several legal issues, such as how to site such facilities, what kinds of marine aquaculture to prioritize, and/or how to control or minimize aquaculture's environmental impacts. Environmentally, for example, while salmon aquaculture can produce significant pollution and escapement problems [7-8], not all types of marine aquaculture create those problems. In the United States, for example, about two-thirds of marine aquaculture production by value consists of clams, mussels, and oysters [2], and these filter-feeding mollusks often improve water quality, especially because most bivalve aquaculture does not require feeding [9-10]. Similarly, escape into the wild is not an issue when aquaculture operations use unmodified native species. In addition, marine aquaculture facilities can also occupy considerable space [3-4]. Some of the newest net pens for finfish aquaculture (such as for raising salmon) encircle 91,000 cubic meters, well over 3 million cubic feet, of the water column and have a circumference of 240 meters (about 787 feet) [11]. The expansion of marine aquaculture can thus result in marine crowding problems, and the siting of aquaculture operations is subject to competing environmental, economic, and social demands upon and priorities regarding ocean space, including food security, traditional and commercial wild-caught fishing, marine protected areas and other protections for environmentally sensitive and high biodiversity ecosystems. coastal infrastructure such as ports and offshore energy facilities, military operations, and cultural heritage [3-4, 6].

Complicating the aquaculture governance situation still further is the fact that the ocean is changing, most notably as a result of overfishing, marine pollution, climate change, and ocean acidification [12-13]. These impacts alter how aquaculture can operate, and numerous aquaculture facilities at various locations around the globe have already had to deal with climate change and/or ocean acidification impacts [14-16]. Notably, under the 2015 Paris climate change agreement, "[o]ver 80 countries have so far included fisheries and/or aquaculture in their priority adaptation areas and actions" [5: 30]. At the same time, climate change and ocean acidification mean that "[p]rimary production of the global ocean, on which the marine food web and ultimately fish rely, is expected to decline by 6 percent by 2100 and by 11 percent in tropical zones," increasing pressure to develop and expand marine aquaculture operations that are "low input and low impact" [5: 131].

Like marine aquaculture expansion, the changes occurring in the ocean have important general implications for marine governance [12-13]. Aquaculture, however, may become a particularly fruitful focus of adapting ocean governance, because much marine aquaculture is inherently adaptable to changing climatic and chemical conditions. While most popular conceptions of marine aquaculture focus on salmon, marine aquaculture production already includes a variety of species, including finfish (e.g., salmon and European sea bass), mollusks (e.g., mussels, clams, and oysters), crustaceans (e.g., crabs and lobsters), sea turtles, sea cucumbers, 
sea urchins, frogs, edible jellyfish, and marine plants such as various forms of seaweed (5: 17). Moreover, "600 aquatic species are now raised in captivity, with different species being preferred for different regions" [17]. The wide variety of species available for marine aquaculture potentially allows producers change species as local ocean temperature increases or marine currents change [18-19]. In addition, emerging siting options for marine aquaculture also increase the industry's adaptability. Marine aquaculture is increasingly moving further out to sea [3-4]. "Open ocean aquaculture is broadly defined as the rearing of marine organisms in exposed areas beyond significant coastal influence" [20: i]. As of 2010, open ocean aquaculture facilities were in operation or under development in Australia, Chile, China, France, Ireland, Italy, Japan, Mexico, Norway, and the United States [20], and Chile specifically is considering shifting its aquaculture zoning further out to sea [21: 174]. In addition to simply providing more space, an open ocean location can protect the aquaculture facility from coastal pollution [20], including increasing coastal runoff as a result of climate change [19]; reduces the pollution impacts of finfish aquaculture [22]; and "releas[e] the coastal zones for other activities like artisanal fisheries, mussel and small-scale farming, and tourism among others" [21: 174]. Finally, colocation of marine aquaculture with other facilities, such as offshore wind farms [3-4, 22], could also increase its adaptability. Especially in the European context, where offshore wind facilities are already common, co-location could support more embryonic marine aquaculture industries. Indeed, in the highly energetic North Sea, co-locating with anchoring wind turbine foundations may be the only way to make marine aquaculture economically feasible [22] - particularly if the North Sea becomes even more energetic in the Anthropocene [19]. Other nations are pursuing co-location as a way of minimizing conflicts and promoting social legitimacy. Brazil, for example, seeks to "integrate aquaculture with other activities developed in the area as a way of mitigating conflicts related to the area's use and also to standardize the system of cultivation so to decrease the various impacts" [21: 152].

Increasing recognition of a changing ocean may lead many coastal nations to legally favor more adaptable and less harmful forms of marine aquaculture [5: 131]. Nevertheless, as aquaculture governance increasingly accommodates both the industry's expansion and its need to adapt, marine aquaculture law and policy will have to become more flexible, ideally promoting the emerging adaptive governance institutions [23-26]. Such flexibility, however, risks social and economic destabilization and raises several issues of social legitimacy [26].

Social legitimacy, of course, has several components, including distributional justice issues and potential displacement of indigenous rights and culture. This article, however, focuses on the legal side of legitimacy, addressing the issue of how the expansion of marine aquaculture can be made more adaptable to a changing environment while simultaneously preserving the traditional rule of law values such as public participation, fairness, predictability, accountability, and compliance with agreed-upon environmental goals [24] that promote the social legitimacy of the resulting enterprises. In particular, this article proposes modifications to the processes of marine spatial planning (MSP), which in many nations and sub-national governmental units (states and territories), has become the legally sanctioned process for allocating marine space [3, 27]-including for marine aquaculture [5, 21, 28]. Informed by work in adaptive management, adaptive governance, and resilience theories, a modified procedural approach to MSP could 
foster socially legitimate adaptive marine aquaculture as well as new institutions of adaptive governance-that is, governance institutions for marine aquaculture that both allow the industry to adapt to changing ocean conditions and increase the industry's ability to accommodate other marine uses and goals. While of course no one model law or statute can possibly work in all coastal countries or in all of the social, ecological, and regulatory contexts in which marine aquaculture occurs, this article highlights the types of substantive and procedural legal innovations that would help to promote adaptive marine aquaculture in many countries.

\section{Adaptive Governance and Its Suitability to Marine Governance for a Changing Ocean}

Adaptive governance is a form of environmental governance. "Governance" "refers to the means ... through which collective goals are chosen, decisions are made, and action is taken to achieve the chosen goals," while "environmental governance" denotes the more specific governance mechanisms "related to society's interactions with natural systems" [25: 3]. Environmental governance must now cope with an obviously changing planet and consequent changes in social-ecological systems $[13,29]$. Adaptive governance is a response to this reality and constitutes "environmental governance that allows emergence of collective action capable of facilitating adaptation to change and surprise as well as the capacity to evolve itself " [25: 3]. "Adaptive governance" thus describes the emergent institutions that can both manage and adapt themselves to changing circumstances [30-32]. While adaptive governance by definition cannot be mandated, societies can enhance the chances that adaptive governance will both emerge and take root as the new governance system [24-25, 30,33]. Such enhancement is an inherently interdisciplinary endeavor $[25,31,33]$.

Because adaptive governance is a response to dynamism and change, much work in this area has focused on water and river basins [33-40]. However, marine systems are also dynamic and complex social-ecological systems [3-4, 12-13], and adaptive governance is of growing interest to researchers into marine governance [31-32]. Indeed, a number of factors render management of marine space increasingly unpredictable, including population growth, climate change, coastal development, ocean acidification, and increasing amounts of offshore development, including offshore wind farms and deepwater marine aquaculture [3-4, 13, 31-32].

Adaptive governance can also be conceptualized as the governance response to resilience theory, which provides the relevant scientific framework for discussing ecological and socialecological dynamism. The Stockholm school of resilience theory posits that all social-ecological systems are constantly changing and hence that there is no balance of nature [41-42]. Instead, these systems move through adaptive cycles of growth or exploitation, conservation, release, and reorganization [42-43]. To add to the dynamism of these systems, adaptive cycles operating at different temporal and geographic scales interact with each other, a model of system complexity that Gunderson and Holling [43] termed "panarchy."

Resilience theory embraces a normality of change [42, 44]. It distinguishes ecological resilience-that is, the capacity of a system to absorb and adapt to disturbance without changing into a different state of being-from engineering or "bounce back" resilience, a system's ability 
to resist shocks and disturbances $[42,45]$. A system that lacks or loses its ecological resilience is vulnerable to transformation from crossing an ecological threshold [41-42, 44, 46]. In the ocean, for example, coastal systems and inland seas already transform because of eutrophication [42] and other kinds of threshold crossings. Marine systems like coral reefs [44, 46-49] and kelp forests [50-51] have undergone phase shifts as a result of overfishing, loss of key species, and other changes in the ocean [31, 41, 44, 52]. In the Anthropocene, climate change [31, 44] and ocean acidification [53] intensify the dynamism of marine systems, generally reducing their ecological resilience and increasingly driving them across thresholds into new (and generally impoverished) states [13, 42].

Adaptive governance also often embraces existing tools that deal with social-ecological dynamism and uncertainty. For example, adaptive management is a structured decision-making process, through which an environmental manager proceeds through cycles of "set-up" phases and "iterative" phases [54-55]. In each set-up phase, the manager engages with stakeholders, sets management goals, and identifies management actions, models, and monitoring plans [5455]. In the iterative phase that follows, the manager engages in a planned experiment by carrying out a management action that the relevant model(s) suggest will take the system toward an identified management goal, monitoring the resulting changes in the system, and then assessing both the management action and the relevant model to provide feedback for the next round of decision-making and action [54-55].

Marine governance is amenable to adaptive management. First, high uncertainty [54-57] exists regarding most marine systems and their responses to overfishing, pollution, climate change, and ocean acidification, among other stressors [58-60]. Second, many human interactions with marine systems (e.g., fishing, marine aquaculture, oil and gas exploration and development, and coastal development) are controllable [54, 56-57, 61]-although, admittedly, the politics surrounding the exercise of increased control can effectively thwart adaptive management. Third, management measures intended to improve a marine system's resilience are unlikely to risk irreversible system collapse [54, 56, 62], although more caution is warranted for measures intended to increase human exploitation [31, 62-63]. Finally, the ocean is both inherently dynamic [31, 54, 56, 64] and changing as a result of the stressors noted above [12-13]. Proving the flexibility of marine governance, adaptive management is already a significant strategy for discovering and managing marine aquaculture's environmental impacts in several parts of the world, including Canada [65], Tasmania, Australia [66], and New Zealand [67]. An expanded culture of adaptive management could help the aquaculture industry to deal with new and increasingly continual impacts on aquaculture itself.

Not all legal problems benefit from adaptive governance. Instead:

Adaptive governance is appropriate when the system is complex ..., the system faces change with a degree of uncertainty . . . and the system is approaching a potential threshold or regime shift as evidenced by increasing conflict over resources (e.g. litigation), increasing scarcity, or actual identification of an approaching threshold by law or science (e.g. listing of species) [33: 10]. 
The expansion of marine aquaculture, as a legal and governance problem, exhibits all of these characteristics. Marine systems are complex systems. As noted, the expansion of marine aquaculture can create conflicts over marine space and other marine resources, and climate change and ocean acidification are increasing uncertainty in ocean management, particularly in "hot spots."

The expansion of marine aquaculture in a changing ocean is thus an appropriate subject for adaptive governance. As such, three aspects of law become important in governance of marine aquaculture: structure, capacity (substantive and participatory), and process [24, 33]. Structurally, the law governing marine aquaculture should be polycentric, but it should also pay attention both to the fitness of responses to the purposes being pursued and to principles of subsidiarity, so that decisions are made at the appropriate scale [24, 33]. Two kinds of legal capacity are important: substantive adaptive capacity, meaning that a community has both the resources and the legal authority to respond to change with appropriate adjustments to substantive requirements $[24,33,68]$; and participatory capacity, meaning that individuals and other relevant stakeholders have both the legal right and the resources to participate in decisionmaking $[24,33]$.

Notably, in regions where climate change and ocean acidification are already producing recognized impacts on aquaculture, polycentric but cohesive responses to the problems have emerged, perhaps portending the future emergence of adaptive governance. For example, in Puget Sound, an ocean acidification "hot spot," state and federal government agencies, researchers, private producers, non-governmental organizations, and foundations are pursuing multiple avenues of research and strategies to help the regional shellfish industry adapt to ocean acidification [53, 69-71]. Similarly, a multi-sectoral effort is striving to find ways to allow Tasmania, Australia's salmon aquaculture adapt to warming temperatures $[18,72]$.

The governance element most overlooked is legal process, the actual procedures through which legal and political decisions are made and implemented [33]. Any functional system of government must foster social and economic stability, but adaptive governance by definition requires increased substantive flexibility, putting adaptive governance potentially in tension with "good governance" goals of fairness and justice and hence threatening the legitimacy of the emergent institutions [26,33]. Legal procedure can mediate this tension and preserve rule-oflaw values during adaptation, increasing the community's sense of fairness and justice [24, 26, 33]. For example, law can require public participation in adaptive decision-making that is both actual, meaning that people realistically can and do participate, and representative, meaning that no groups or interests are ignored or silenced, through appropriate notice, public comment, and public meeting (or, increasingly, on-line forum) requirements. Law can ensure that decisionmakers remain accountable to both the general public and to overall social and legal goals (such as environmental protection and maintaining economic well-being while adapting) through a variety of mechanisms, including: (1) requirements that decision-makers respond meaningfully to public comments before reaching a final decision; (2) limitations on discretion as decisionmakers and their agents implement adaptive governance mechanisms (such as adaptive 
management); (3) clear goals and standards against which to judge the effectiveness of adaptive actions; and (4) provision of (or in some countries, creation of) avenues of administrative and judicial review that concerned or aggrieved citizens can use to challenge government decisions and actions, perhaps with fee-shifting provisions to encourage this form of public interest litigation. Finally, legal procedures can minimize widespread and/or continual social destabilization by matching the pace of legal and governance change to the pace of the biophysical, social, and/or economic changes that are occurring [24, 26, 33]. For example, decisions on how to adapt to sea-level rise generally do not need to occur as frequently as decisions on how to respond to intensifying marine pollution.

As noted, MSP is a common procedure in marine governance, including, increasingly, marine aquaculture governance. However, MSP can become both more adaptable to changing ocean conditions and more supportive of rule-of-law values, as the next section will explore.

\section{Legitimizing Adaptive Marine Aquaculture through Enhanced Marine Spatial Planning}

Law can address new natural resource management issues in several modes. Substantive legal intervention is a common response to natural resource issues, and law can use many substantive requirements to enhance marine resilience and support adaptive governance in the context of marine aquaculture. For example, legislatures, agencies, and courts can create rules that reduce the impacts of marine aquaculture on the marine environment $[8,73]$. Alternatively, law can promote the more environmentally benign forms of marine aquaculture, such as shellfish aquaculture. In March 2018, the State of Washington in the U.S. prohibited [74], while litigation in Tasmania, Australia, may limit [75] salmon aquaculture.

However, carefully designed procedural innovations can often be equally effective in addressing natural resources issues. As noted, many coastal nations are already engaging in MSP, the process of figuring out how to best use and manage the different geographic areas of a particular ocean jurisdiction [5, 12, 27], including for aquaculture $[5,21,28]$. In this planning process, coastal governments figure out what human uses they want to promote, what areas of the ocean must be protected in order to achieve biodiversity and conservation goals, and which uses and goals are mutually compatible and which need to be separated, often resulting in the establishment of various marine zones for different uses [5, 12, 27]. MSP is an inherently flexible planning and management tool $[5,12,27]$ that can address substantive issues. Chile, for example, used MSP and marine zoning to mitigate the environmental impacts of its rapidly expanding salmon aquaculture industry [21: 170-172], while in of Norway, the United Kingdom, and Northern Ireland, marine zoning of aquaculture has "helped protect the environment, minimise disease impact and support the industry to flourish in a sustainable manner" [21: 198].

MSP in many coastal nations already provides procedures for enhancing decision-making legitimacy. In introducing marine zoning for aquaculture to China and Indonesia, for example, the United Nations Food \& Agriculture Organization (FAO) stressed the importance of government transparency in planning, licensing, and on-going management [21: 199]-a rule-of-law legitimacy concern that is also key to government accountability. Similarly, MSP lends itself to 
extensive public participation and the incorporation of stakeholders' interests [5, 12. 27]. Indeed, the FAO has emphasized the importance of stakeholder involvement in the use of MSP to site marine aquaculture [21]. Chile, for example, engaged in multiple rounds of meetings with a variety of stakeholders before establishing its aquaculture zones [21: 172-173]. Stakeholder roundtables and other interactions among stakeholders and between multiple stakeholders and government are already considered core elements of MSP [21: 208, 210], rooting MSP in a multifaceted dialogue that promotes the legitimacy of the resulting plan and hence adherence to the rule of law and a perception of overall fairness.

Nevertheless, truly adaptive marine aquaculture-aquaculture that continually adapts to changing ocean conditions and is managed through new adaptive governance institutions-may well raise new concerns for these rule-of-law values that support social legitimacy. Specifically, the legitimacy of truly adaptive marine aquaculture will likely depend upon procedural innovation that increases public participation, forums for creative discussion and problemsolving, and decision-making accountability.

What is currently generally lacking in much MSP procedure for the Anthropocene are legal spurs to continuing adaptation and legal dynamism-i.e., an iterative approach to MSP that can continually respond to changing environmental, social, and economic conditions while simultaneously fostering the continued interactions among key stakeholders from which new adaptive governance institutions are likely to emerge. While the European Union requires regular review of marine spatial plans [76], elsewhere MSP is rarely a continual process that encourages questioning of its own conclusions over time. As one example, Australia is a recognized leader in MSP, beginning to zone the Great Barrier Reef Marine Park in the late 1970s and early 1980s. Even so, the two Great Barrier Reef plans have been, essentially "final products" (maps), not continually evolving management measures for a dramatically changing system [77-78]. Static and outdated marine spatial plans can hinder adaptive aquaculture. For example, when Bali, in Indonesia, sought to expand its marine aquaculture industry in a more sustainable way, it found that "the adopted spatial planning and siting of aquaculture facilities currently in place is inappropriate" [21: 223].

In addition, increased legal procedural connectivity would often help to increase the adaptivity of MSP processes. Specifically, legal procedures that link adaptive management of marine aquaculture, polycentric responses to emerging problems, and MSP to each other and to systemic goals for marine governance could more emphatically encourage continual public discussion about, re-evaluation of, and experimentation with uses of the marine environment as the ocean changes. The State of Washington on the United States' Pacific coast can provide an illustrative example. When Washington completed its MSP recently, it simply concluded that existing aquaculture installations precluded most future wind development in state waters [79]. What if, instead of being the end result of the MSP process, this and similar conclusions became the beginning of the next round of public discussion? For example, acknowledging that the preclusion of offshore wind undermined a desirable systemic goal of marine governance (promotion of renewable energy), Washington law might require the relevant state agencies to then convene further public discussions regarding whether Washington should nevertheless 
pursue offshore wind development in its coastal waters and, if so, how offshore wind and aquaculture might accommodate each other. Such discussions might in turn prompt members of the two industries and research institutions to collaborate on an experimental co-located facility-a small wind farm constructed to support one or two types of aquaculture [4]. Washington might also enact offshore permitting regulations that gave procedural and substantive preference to combined-use facilities but that also required experimental facilities to engage in true adaptive management, with public participation, reporting, and accountability obligations akin to those in Craig and Ruhl's [54] Model Adaptive Management Procedure Act. By mandating participatory forums that could foster creative but polycentric approaches to ocean management issues and by implementing legal procedures that foster public participation, scientific and technical experimentation and learning, and increased collaboration, Washington might well find that socially legitimate adaptive governance emerge, resulting in new governance institutions that could allow its marine aquaculture industry to more nimbly and painlessly adapt to climate change and ocean acidification while simultaneously making room for other innovative uses of the ocean-all while preserving the transparency, public participation, and sense of fairness that would make such innovations socially legitimate.

\section{Conclusion}

A changing world demands new approaches to governance, but the drive to adapt must still respect the need for law and policy innovations to be socially legitimate and to foster rather than undermine the rule of law. While marine aquaculture increasing contributes to world food security, how and where to expand that industry is inherently a governance-and often specifically legal-issue. Given the realities of the Anthropocene and the inherent adaptability of marine aquaculture, governments should be looking for ways to promote legitimate adaptive governance in marine aquaculture.

While innovation in substantive law can help, coastal nations should pay increasing attention to the legal procedures of marine governance, especially MSP. Attention to procedure-specifically, to ensuring broad, representative, and actual participation by stakeholders, continuing dialogues that foster trust, and transparency in decision-making that clearly connects stakeholder discussions to decisions made-can allow for legal flexibility and adaptive marine aquaculture that nevertheless remains socially legitimate and acceptable. The key is to reconceive of MSP as an iterative, rather than linear, process that mandates multiple ongoing forums for public participation and collaboration regarding the uses of and priorities for marine space, increases incentives for polycentric collaboration and creativity, and encourages experimentation and scientific learning through adaptive management.

\section{Acknowledgements}

This research was made possible, in part, through generous support from the Albert and Elaine Borchard Fund for Faculty Excellence and from the Rockefeller Foundation's Bellagio Center Writing Residency Program. 


\section{Glossary}

Adaptive Cycle: A model of the continual and dynamic progression of social-ecological systems through phases of growth (exploitation), conservation, release, and reorganization.

Adaptive Governance: Environmental governance "that allows emergence of collective action capable of facilitating adaptation to change and surprise as well as the capacity to itself evolve" $[25$, p. 3].

Adaptive Management: A structured and iterative decisionmaking process for engaging in controlled experiments in managing dynamic systems, characterized by monitoring of results, evaluation and assessment of the management actions undertaken, and feedback to inform the next management actions.

Ecological Resilience: The capacity of a system to absorb and adapt to shocks and disturbances without crossing a threshold into a new state.

Engineering Resilience: The capacity of a system to resist or bounce back from a shock or disturbance, that is, to maintain an existing state or to re-establish its previous state.

Environmental Governance: The specific governance mechanisms "related to society's interactions with natural systems" [25: 3]. Such mechanisms can take a variety of forms, ranging from environmental impact analyses to resource use permitting to community-based management to market mechanisms such as pollution trading.

Governance: The structures, institutions, and processes through which people in communities set goals and priorities, make decisions, allocate resources, and share power.

Panarchy: A set of nested dynamic systems operating through adaptive cycles at different geographic and temporal scales, allowing the relative stability (conservation phase) or change (release and reorganization phases) of systems at one scale to temper or reinforce, respectively, the dynamism of systems operating at other scales.

Resilience Theory: The Stockholm school of resilience theory, which emphasizes that systems are always changing through adaptive cycles; that ecological resilience differs from engineering resilience; and that systems can shift phases and cross thresholds, transforming into entirely new states of being.

Social-Ecological System: An admittedly imperfect term that nevertheless acknowledges that neither ecosystems nor human systems exist in isolation from each other but instead are always mutually influential and dependent. 


\section{REFERENCES}

[1] United Nations Food and Agriculture Organization, The State of World Fisheries and Aquaculture: Contributing to Food Security and Nutrition for All, United Nations, Geneva, Switzerland, 2016.

[2] National Oceanic \& Atmospheric Administration, Aquaculture in the United States <http://www.nmfs.noaa.gov/aquaculture/aquaculture_in_us.html> (as viewed May 29, 2018).

[3] R.K. Craig, It's Not Just an Offshore Wind Farm: Combining Multiple Uses and Multiple Values on the Outer Continental Shelf, Public Land \& Resources L. Rev. 39 (2018) 59-122.

[4] R.K. Craig, Harvest the Wind, Harvest Your Dinner: Using Law to Encourage an Offshore Energy-Food Multiple Use Nexus, Jurimetrics 59 (2018) (in press).

[5] Food \& Agriculture Organization of the United Nations, The State of World Fisheries and Aquaculture: Meeting the Sustainable Development Goals, Rome, Italy, 2018.

[6] R.R. Gentry, H.E. Froehlich, D. Grimm, P. Kareiva, M. Parke, M. Rust, S.D. Gaines, B.S. Halpern, Mapping the global potential for marine aquaculture, Nature Ecology \& Evolution 1 (2017) 13171324. http://doi.org/10.1038/s41559-017-0257-9.

[7] E.R. Englebrecht, Can Aquaculture Continue to Circumvent the Regulatory Net of the Magnuson-Stevens Fishery Conservation and Management Act?, Emory L.J. 51 (2002) 1187-1246.

[8] P. Read, T. Fernandes, Management of environmental impacts of marine aquaculture in Europe, Aquaculture 226 (2003) 139-163. http://doi.org/10.1016/S0044-8486(03)00474-5.

[9] L.E. Steeves, R. Filgueira, T. Guyondet, J. Chassé, L. Comeau, Past, Present, and Future: Performance of Two Bivalve Species Under Changing Environmental Conditions, Frontiers in Marine Science 5 (2018) 184. https://doi.org/10.3389/fmars.2018.00184.

[10] O. Lindahl, R. Hart, B. Hernroth, S. Kollberg, L.-O. Loo, L. Olrog, A.-S. Rehnstam-Holm, J. Svensson, S. Svensson, U. Syversen, Improving Marine Water Quality by Mussel Farming: A Profitable Solution for Swedish Society, Ambio 34 (2005) 131-138. https://doi.org/10.1579/00447447-34.2.131.

[11] Huon Aquaculture, Revolutionary New Net Pen Design. <https://www.huonaqua.com.au/about/farm/new-pens/> (as viewed May 29, 2018).

[12] R.K. Craig, Comparative Ocean Governance: Place-Based Protections in an Era of Climate Change, Edward Elgar Press, Cheltelham, UK \& Northamption, MA, 2012. 
[13] M.H. Benson, R.K. Craig, The End of Sustainability: Resilience and the Future of Environmental Governance in the Anthropocene, University of Kansas Press, Lawrence, KS, USA, 2017.

[14] B.F. Phillips, M. Pérez-Ramírez, Climate Change Impacts on Fisheries and Aquaculture: A Global Analysis, John Wiley \& Sons Ltd., Chichester, West Sussex, UK, 2018.

[15] J.C. Clements, T. Chopin, Ocean acidification and marine aquaculture in North America: potential impacts and mitigation strategies, Reviews in Aquaculture 9 (2017) 326-341, doi: 10.1111/raq.12140.

[16] S.C. Mangi, J. Lee, J.K. Pinnegar, R.J. Law, E. Tyllianakis, S.N.R. Birchenough, The economic impacts of ocean acidification on shellfish fisheries and aquaculture in the United Kingdom, Environmental Science \& Policy 86 (2018) 95-105, https://doi.org/10.1016/j.envsci.2018.05.008.

[17] World Ocean Review, Aquaculture-protein provider for the world. <http://worldoceanreview.com/en/wor-2/aquaculture/protein-provider-for-the-world/> (as viewed May 29, 2018).

[18] S. Battaglene, C. Carter, A.J. Hobday, V. Lyne, B. Nowak, Scoping Study into Adaptation of the Tasmanian Salmonid Aquaculture Industry to Potential Impacts of Climate Change, Tasmanian Aquaculture and Fisheries Institute, University of Tasmania and CSIRO Marine and Atmospheric Research, Hobart, Tasmania, Australia, 2008. http://www.imas.utas.edu.au/_data/assets/pdf_file/0003/743304/Salmonid_Climate_Change Final_Report_Distribution.pdf.

[19] R. Callaway, A.P. Shinn, S.E. Grenfell, J.E. Bron, G. Burnell, E.J. Cook, M. Crumlish, S. Culloty, K. Davidson, R.P. Ellis, K.J. Flynn, C. Fox, D.M. Green, G.C. Hays, A.D. Hughes, E. Johnston, C.D. Lowe, I. Lupatsch, S. Malham, A.F. Mendzil, T. Nickell, T. Pickerell, A.F. Rowley, M.S. Stanley, D.R. Tocher, J.F. Turnbull, G. Webb, E. Wootton, R. J. Shields, Review of climate change impacts on marine aquaculture in the UK and Ireland, Aquatic Conservation: Marine \& Freshwater Ecosystems 22 (2012) 389-421. https://doi.org/10.1002/aqc.2247.

[20] H.H. Upton, E.F. Buck, Open Ocean Aquaculture, Congressional Research Services, Washington, D.C., USA, 2010. http://nationalaglawcenter.org/wpcontent/uploads/assets/crs/RL32694.pdf.

[21] J. Aguilar-Manjarrez, D. Soto, R. Brummett, Aquaculture zoning, site selection and area management under the ecosystem approach to aquaculture: A handbook, Food \& Agriculture Organization of the United Nations \& The World Bank, Rome, Italy, 2017.

[22] N. Christie, K. Smyth, R Barnes, M. Elliott, Co-location of activities and designations: A means of solving or creating problems in marine spatial planning?, Marine Policy 43 (2014) 254-261. http://dx.doi.org/10.1016/j.marpol.2013.06.002. 
[23] J.D. Bell, A. Ganachaud, P.C. Gehrke, S.P. Griffiths, A.J. Hobday, O. Hoegh-Guldberg, J.E. Johnson, R. Le Borgne, P. Lehodey, J.M. Lough, R.J. Matear, T.D. Pickering, M.S. Pratchett, A.S. Gupta, I. Senina, M. Waycott, Mixed responses of tropical Pacific fisheries and aquaculture to climate change, Nature Climate Change 3 (2013) 591-599. http://doi.org/10.1038/nclimate1838.

[24] B.A. Cosens, R.K. Craig, S.L. Hirsch, C.A. Arnold, M.H. Benson, D.A. DeCaro, A.S. Garmestani, H. Gosnell, J.B. Ruhl, E. Schlager, The role of law in adaptive governance, Ecology \& Society 22 (2017) art. 30. https://doi.org/10.5751/ES-08731-220130.

[25] B.A. Cosens, L, Gunderson, B.C. Chaffin, Introduction to the Special Feature Practicing Panarchy: Assessing legal flexibility, ecological resilience, and adaptive governance in regional water systems experiencing rapid environmental change, Ecology \& Society 23 (2018) art. 4. https://doi.org/10.5751/ES-09524-230104.

[26] R.K. Craig, A.S. Garmestani, C.R. Allen, C.A. Arnold, H. Birgé, D.A. DeCaro, A.K. Fremier, H. Gosnell, E. Schlager, Balancing stability and flexibility in adaptive governance: an analysis of tools available in U.S. environmental law, Ecology \& Society 22 (2017) art. 3. https://doi.org/10.5751/ES-08983-220203.

[27] T. Agardy, Ocean Zoning: Making Marine Management More Effective, Earthscan, London, UK, \& Washington, D.C., USA, 2010.

[28] G.J. Meaden, J. Aguilar-Manjarrez, R.A. Corner, A.M. O'Hagan, F. Cardia, Marine spatial planning for enhanced fisheries and aquaculture sustainability: Its application in the Near East, Food \& Agriculture Organization of the United Nations, Rome, Italy, 2016.

[29] R.K. Craig, "Stationarity Is Dead"-Long Live Transformation: Five Principles for Climate Change Adaptation Law, Harvard Envtl. L. Rev. $34 \quad$ (2010) 9-73. http://www.law.harvard.edu/students/orgs/elr/vol34_1/9-74.pdf.

[30] B.C. Chaffin, H. Gosnell, B.A. Cosens, A decade of adaptive governance scholarship: Synthesis and future directions, Ecology \& Society 19 (2014) art. 56. http://dx.doi.org/10.5751/ES-06824190356.

[31] T.P. Hughes, D.R. Bellwood, C. Folke, R.S. Steneck, J. Wilson, New paradigms for supporting the resilience of marine ecosystems, Trends in Ecology \& Evolution 20 (2005) 380-386. https://doi.org/10.1016/j.tree.2005.03.022.

[32] C. Cvitanovic, A.J. Hobday, L. van Kerkhoff, S.K. Wilson, K. Dobbs, N.A. Marshall, Improving knowledge exchange among scientists and decision-makers to facilitate the adaptive governance of marine resources: A review of knowledge and research needs, Ocean \& Coastal Management 112 (2015) 25-35. http://dx.doi.org/10.1016/j.ocecoaman.2015.05.002. 
[33] B. Cosens, L, Gunderson, B, Chaffin, The adaptive water governance project: assessing law, resilience and governance in regional socio-ecological water systems facing a changing climate, Idaho L. Rev. $51 \quad$ (2014) 1-27. https://www.uidaho.edu/-/media/UldahoResponsive/Files/law/law-review/articles/volume-51/51-1-cosens-barbara-etalintroduction.ashx?la=en\&hash=3F7382635EAC10440D4EACFBAA598B07C0C91190.

[34] C.A. Arnold, O.O. Green, D. DeCaro, A. Chase, J.-G. Ewa, The Socio-Ecological Resilience of an Eastern Urban-Suburban Watershed: The Anacostia River Basin, Idaho L. Rev. 51 (2014) 29-90. https://www.uidaho.edu/-/media/Uldaho-Responsive/Files/law/law-review/articles/volume51/51-1-arnold-craig-anthonyetal.ashx?la=en\&hash=29A9C06A9C794A070040091923B1DA1417EBB39B.

[35] M.H. Benson, D. Llewellyn, R. Morrison, M. Stone, Water Governance Challenges in New Mexico's Middle Rio Grande Valley: A Resilience Assessment, Idaho L. Rev. 51 (2014) 195-228. https://www.uidaho.edu/-/media/Uldaho-Responsive/Files/law/law-review/articles/volume51/51-1-benson-melinda-harmetal.ashx?la=en\&hash=B07FF458CA1EF24EAE92D50ECD9C9EB2DC489D27.

[36] H.E. Birgé, C.R. Allen, R.K. Craig, A.S. Garmestani, J.A. Hamm, C. Babbitt, K. Nemec, E. Schlager, Social-Ecological Resilience and Law in the Platte River Basin, Idaho L. Rev. 51 (2014) 229-257. https://www.uidaho.edu/-/media/Uldaho-Responsive/Files/law/lawreview/articles/volume-51/51-1-birge-hannahetal.ashx?la=en\&hash=513F3A339BBED063CC4DBB60A581D7317EF57BB4.

[37] B.C. Chaffin, R.K. Craig, H. Gosnell, Resilience, Adaptation, and Transformation in the Klamath River Basin Social-Ecological System, Idaho L. Rev. 51 (2014) 157-193. https://www.uidaho.edu/-/media/Uldaho-Responsive/Files/law/law-review/articles/volume51/51-1-chaffin-brian-cetal.ashx?la=en\&hash=CC21EBF84115BA1A554572C3C66E2FE6897F88BA.

[38] O.O. Green, A.S. Garmestani, C.R. Allen, L.H. Gunderson, J. B. Ruhl, C.A. Arnold, N.A.J. Graham, B. Cosens, D.G. Angeler, B.C. Chaffin, C. S. Holling, Barriers and bridges to the integration of social-ecological resilience and law, Frontiers in Ecology \& Envt. 13 (2015) 332-337. http://dx.doi.org/10.1890/140294.

[39] B. Cosens, A. Fremier, Assessing System Resilience and Ecosystem Services in Large River Basins: A Case Study of the Columbia River Basin, Idaho L. Rev. 51 (2014) 91-125. https://www.uidaho.edu/-/media/Uldaho-Responsive/Files/law/law-review/articles/volume-

51/51-1-cosens-barbara-

etal.ashx?la=en\&hash=FEF4E4BE6CEC21944154C8820D1E592599AAD06D.

[40] L.H. Gunderson, A. Garmestani, K.W. Rizzardi, J.B. Ruhl, A. Light, Escaping a Rigidity Trap: Governance and Adaptive Capacity to Climate Change in the Everglades Social Ecological System, Idaho L. Rev. 51 (2014) 127-156. https://www.uidaho.edu/-/media/Uldaho- 
Responsive/Files/law/law-review/articles/volume-51/51-1-gunderson-lanceetal.ashx?la=en\&hash=329A43E885776419D7E4DE9D4541905A6D6B5C74.

[41] C. Folke, S. Carpenter, B. Walker, M. Sheffer, T. Elmqvist, L. Gunderson, C.S. Holling, Regime shifts, resilience and biodiversity in ecosystem management, Ann. Rev. Ecology, Evolution, \& Systematics 35 (2004) 557-581. http://doi.org/10.1146/annurev.ecolsys.35.021103.105711.

[42] B. Walker, D. Salt, Resilience Thinking: Sustaining Ecosystems and People in a Changing World, Island Press, Washington, D.C., USA, 2006.

[43] L. Gunderson, C.S. Holling, Panarchy: understanding transformations in human and natural systems, Island Press, Washington, D.C., USA, 2002.

[44] M. Scheffer, S. Carpenter, J.A. Foley, C. Folke, B. Walker, Catastrophic shifts in ecosystems. Nature 413 (2001) 591-596. http://doi.org/10.1038/35098000.

[45] C.S. Holling, Resilience and stability of ecological systems, Ann. Rev. Ecology \& Systematics 4 (1973) 1-23. https://doi.org/10.1146/annurev.es.04.110173.000245.

[46] M. Scheffer, S.R. Carpenter, Catastrophic regime shifts in ecosystems: linking theory to observation, Trends in Ecology \& Evolution 18 (2003) 648-656. http://doi.org/10.1016/j.tree.2003.09.002.

[47] R.B. Aronson, W.F. Precht, Herbivory and algal dynamics on the coral reef at Discovery Bay, Jamaica, Limnology \& Oceanography $45 \quad$ (2000) 251-255. https://doi.org/10.4319/lo.2000.45.1.0251.

[48] D.R. Bellwood, T.P. Hughes, C. Folke, M. Nyström, Confronting the coral reef crisis. Nature 429 (2004) 827-833. http://doi.org/10.1038/nature02691.

[49] J.W. McManus, J.F. Polsenberg, Coral-algal phase-shifts on coral reefs: ecological and environmental aspects, Progress in Oceanography 60 (2004) 263-279. https://doi.org/10.1016/j.pocean.2004.02.014.

[50] R.S. Steneck, M.H. Graham, B.J. Bourque, D. Corbett, J.M. Erlandson, J.A. Estes, M.J. Tegner, Kelp forest ecosystems: biodiversity, stability, resilience and future, Envtl. Conservation 29 (2002) 436-459. https://doi.org/10.1017/S0376892902000322.

[51] R.S. Steneck, J. Vavrinec, A.V. Leland, Accelerating trophic-level dysfunction in kelp forest ecosystems of the Western North Atlantic, Ecosystems 7 (2004) 323-332. http://doi.org/10.1007/s10021-004-0240-6. 
[52] D. Pauly, V. Christensen, S. Guénette, T.J. Pitcher, U.R. Sumaila, C.J. Walters, R. Watson, D. Zeller, Towards sustainability in world fisheries, Nature 418 (2002) 689-695. http://doi.org/10.1038/nature01017.

[53] R.K. Craig, Dealing with Ocean Acidification: The Problem, the Clean Water Act, and State and Regional Approaches, Washington L. Rev. $90 \quad$ (2015) 1583-1657. https://digital.law.washington.edu/dspacelaw/bitstream/handle/1773.1/1612/6WJELP387.pdf?sequence=1\&isAllowed=y.

[54] R.K. Craig, J.B. Ruhl. Designing Administrative Law for Adaptive Management, Vanderbilt L. Rev. $67 \quad$ (2014) 1-87. https://www.vanderbiltlawreview.org/wpcontent/uploads/sites/89/2014/01/CraigRuhl-67-Vand.-L.-Rev.-1.pdf.

[55] R.K. Craig, J.B. Ruhl, E.D. Brown, B.K. Williams, Designing Administration Law for Adaptive Management, Envtl. Research Letters 12 (2017): 074018. https://doi.org/10.1088/17489326/aa7037.

[56] C.R. Allen, L.H. Gunderson, Pathology and Failure in the Design and Implementation of Adaptive Management, J. Envtl. Management 92 (2011) 1379-1384. https://doi.org/10.1016/j.jenvman.2010.10.063.

[57] B.K. Williams, Adaptive Management of Natural Resources-Framework and Issues, J. Envtl. Management 92 (2011) 1346-1353. https://doi.org/10.1016/j.jenvman.2010.10.041.

[58] L.W. Botsford, A.M. Parma, Uncertainty in Marine Management, in E.A. Norse, L.B. Crowder, eds. (Marine Conservation Biology Institute), Marine Conservation Biology: The Science of Maintaining the Sea's Biodiversity 375-392, Island Press, Washington, D.C., USA, 2005.

[59] R.Q. Grafton, T. Kompas, Uncertainty and the active adaptive management of marine reserves, Marine Policy 29 (2005) 471-479. https://doi.org/10.1016/j.marpol.2004.07.006.

[60] J. Rodrigues, A.J. Garcia, S.R. Conides, S. Rodriguez, P. Raicevich, K.M. Pita, C. Kleisner, P.F.M. Pita, V.A. Lopes, S.S. Roldán, D. Ramos, L. Klaoudatos, C. Outeiro, L. Armstrong, S. Teneva, A. Stefanski, M. Böhnke-Henrichs, A.I. Kruse, E.M. Lillebø, A. Bennett, A. Belgrano, I.S. Murillas, B. Pinto, S.V. Burkhard, Global Marine and Coastal Cultural Ecosystem Services: Knowledge gaps and research priorities, One Ecosystem 2 (2014) e12290. https://doi.org/10.3897/oneeco.2.e12290.

[61] W.K. de la Mare, Marine ecosystem-based management as a hierarchical control system, Marine Policy 29 (2005) 57-68. https://doi.org/10.1016/j.marpol.2004.02.002.

[62] B. Worm, E.B. Barbier, N. Beaumont, J.E. Duffy, C. Folke, B.S. Halpern, J.B. C. Jackson, H.K. Lotze, F. Micheli, S.R. Palumbi, E. Sala, K.A. Selkoe, J.J. Stachowicz, R. Watson, Impacts of 
Biodiversity Loss on Ocean Ecosystem Services, Science 314 (2006) 787-790. http://doi.org/10.1126/science.1132294.

[63] J.A. Hutchings, Collapse and recovery of marine fisheries, Nature 409 (2000) 882-885. http://doi.org/10.1038/35022565.

[64] S.M. Maxwell, E.L. Hazen, R.L. Lewison, D.C. Dunn, H. Bailey, S.J. Bograd, D.K. Briscoe, S. Fossette, A.J. Hobday, M. Bennett, S. Benson, M.R. Caldwell, D.P. Costa, H. Dewar, T. Eguchi, L. Hazen, S. Kohin, T. Sippel, L.B. Crowder, Dynamic ocean management: Defining and conceptualizing real-time management of the ocean, Marine Policy 58 (2015) 42-50. http://dx.doi.org/10.1016/j.marpol.2015.03.014.

[65] Fisheries and Oceans Canada, Development of monitoring and assessment tools for adaptive management of salmon aquaculture relative to sensitive marine invertebrate habitat, 2002 <http://www.dfo-mpo.gc.ca/aquaculture/rp-pr/acrdp-pcrda/projects-projets/MG-01-06-010eng.html> (as viewed May 29, 2018).

[66] C. Crawford, Environmental management of marine aquaculture in Tasmania, Australia, Aquaculture 226 (2003) 129-138. https://doi.org/10.1016/S0044-8486(03)00473-3.

[67] J. Innes, Is Adaptive Management the Way Forward?, The Fish Site, 2011 $<$ https://thefishsite.com/articles/is-adaptive-management-the-way-forward> (as viewed May 29, 2018).

[68] C. Folke, T. Hahn, P. Olsson, J. Norberg, Adaptive governance of social-ecological systems, $\begin{array}{llllll}\text { Annual Rev. } \quad \text { Envt. \& } \quad \text { Resources. } 30 & \text { (2005) 441-473. }\end{array}$ http://dx.doi.org/10.1146/annurev.energy.30.050504.144511.

[69] C. Welch, Willapa Bay oyster grower sounds alarm, starts hatchery in Hawaii, The Seattle Times, 2012 <https://www.seattletimes.com/seattle-news/willapa-bay-oyster-grower-soundsalarm-starts-hatchery-in-hawaii/> (as viewed May 29, 2018).

[70] P. Le, Studies testing kelp to ease effects of ocean acidification, The Seattle Times, 2016 <https://www.seattletimes.com/seattle-news/studies-testing-kelp-to-ease-effects-of-oceanacidification/> (as viewed May 29, 2018).

[71] L. Stiffler, Climate Change Turns Puget Sound Acidic and Region's Signature Oysters Struggle to Survive, InvestigateWest, 2017 <http://www.invw.org/2017/07/10/as-climate-change-turnspuget-sound-acidic-can-regions-signature-oysters-survive/> (as viewed May 29, 2018).

[72] C.M. Spillman, A.J. Hobday, Dynamical seasonal ocean forecasts to aid salmon farm management in a climate hotspot, Climate Risk Management 1 (2014) 25-38. https://doi.org/10.1016/j.crm.2013.12.001. 
[73] Harvard Law School Emmett Environmental Law \& Policy Clinic, Environmental Law Institute, and the Ocean Foundation, Offshore Aquaculture Regulation under the Clean Water Act, Environmental Law Institute, Washington, D.C., USA, 2012. http://eli-ocean.org/wpcontent/blogs.dir/3/files/CWA-aquaculture.pdf.

[74] L.V. Mapes, State kills Atlantic salmon farming in Washington, The Seattle Times, 2018 $<$ https://www.seattletimes.com/seattle-news/politics/bill-to-phase-out-atlantic-salmonfarming-in-washington-state-nears-deadline/> (as viewed May 29, 2018).

[75] M. Maloney, Salmon future pondered in Macquarie Harbour expansion case, The Examiner, $2018<$ https://www.examiner.com.au/story/5301563/salmon-future-pondered-in-macquarieharbour-expansion-case/> (as viewed May 29, 2018).

[76] N. Soininen, Marine Spatial Planning in the European Union, in D. Hassan, T. Kuokkanen, \& N. Soininen, eds., Transboundary Marine Spatial Planning and International Law 189-201, Routledge, New York, NY, USA, 2017 paperback edition.

[77] United Nations Education, Scientific, \& Cultural Organization, Intergovernmental Oceanographic Commission, Marine Spatial Planning Programme: Australia (Great Barrier Reef), <http://msp.ioc-unesco.org/world-applications/oceania/australia/great-barrier-reef/> (as viewed May 29, 2018).

[78] Coral Reef Studies, ARC Centre of Excellence, Coral bleaching and the Great Barrier Reef, <https://www.coralcoe.org.au/for-managers/coral-bleaching-and-the-great-barrier-reef> (as viewed May 29, 2018).

[79] Washington Department of Ecology, Washington Department of Fish \& Wildlife, and Washington Department of Natural Resources, Draft Marine Spatial Plan for Washington's Pacific Coast, Washington Department of Ecology, Olympia, WA, USA, 2017. http://www.msp.wa.gov/wp-content/uploads/2017/draft_MSP_and_appendices.pdf. 